\title{
Integrating property management into overall business and financial planning
}

Received (in revised form): 11 May 2006

\section{Robin Priest}

joined Deloitte Corporate Finance as a Partner in May 2005. Robin leads the Real Estate Transaction Advisory team in Deloitte and is currently advising clients and working with investors on sale and leasebacks, public private partnerships, mergers and acquisitions and real estate financing strategies. Robin brings his deep expertise of corporate real estate, real estate transactions, financing and private equity. Prior to joining Deloitte, Robin was the founder and Managing Director of Beachwood Partners Limited, a strategic consultancy for the outsourcing, property and services industries. Robin was the founder and Chief Executive of Mapeley Limited - a long term serviced and flexible accommodation outsourcing company. He successfully led the bids for and mobilisation of two major outsourcing contracts, HM Revenue and Customs and Excise and Abbey. Prior to Mapeley, Robin spent 20 years in banking as a structured financier working in the Asian, European, and North American markets.

\begin{abstract}
Property is often treated as integral to an organisation's core business needs, but rarely as being integral to business or financial planning. The current surge in real estate values, driven primarily by the sheer amount of capital chasing propertyrelated investment, is bringing the real estate debate into sharp focus for operating businesses that are property-heavy.

Sale and leasebacks of retail and leisure assets have been concluded at EBITDA multiples of between 14 and 17 times. Business acquisition multiples in the same sectors have been between 8 and 10 times. More recently, the two sets of multiples have been migrating towards each other. The premise for investors is that they can achieve superior yields by assuming greater risk in previously non-core activity.

The heat being generated in the real estate market is leading most retail and leisure businesses to consider realising capital from their real estate assets. Although conceptually simple, releasing value from the property assets is complex from an operational, fiscal, and accounting standpoint. Businesses should consider the opportunity to take advantage of real estate investor demand very carefully and should at all times keep all aspects and consequences of the transaction in view.
\end{abstract}

Robin Priest Deloitte

Athene Place 66 Shoe Lane London $\mathrm{EC}_{4} \mathrm{~A} 3 \mathrm{BQ}$, UK Tel: 02070078519 Fax: 02070071077 E-mail: rpriest@deloitte.co.uk

\section{Keywords:}

retail property, leisure property, asset management, sale and leaseback (S\&LB), OpCo PropCo, REIT

Journal of Retail and Leisure Property (2006) 5, 235-238. doi:10.1057/palgrave.rlp.5100025 
Property has come to be viewed as a special case: a physical asset with intrinsic value. Perhaps this arose out of the inevitability with which property value grows. Or, alternatively it is because property is used as a comfort blanket: management and the Board take solace from the robustness it lends to a company's balance sheet and the performance of property investments made in the past.

The retail and leisure sectors need property: it is the physical platform from which the core business delivers its service or sells its product. Historically the view has been that companies need control over the property they use: they need to secure the best pitch and to avoid overexposure to rental growth. Control has usually been seen as meaning ownership. Some have seen freehold property as being 'free' to the business on the basis that there is no rent to pay to a third party. The fact is that the clear separation of property from the business and from finance and its lack of transparency have lead to misconceptions and misunderstandings.

Although property has been treated as integral to an organisation's core business needs, it is often not treated as being integral to business or financial planning. The surge in real estate values in recent years, driven primarily by the sheer amount of property-related investment and the willingness of the debt markets to magnify the buying power of that capital, has brought the real estate debate into sharp focus for operating businesses that are property-heavy.

Two phenomena are now well-established:

- Acquirers of operating businesses are pre-refinancing their purchases by teaming up with property investors at an early stage; and

- Property-orientated investors are themselves bidding for operating businesses - particularly in the leisure sector — in order to access property stock.

The premise for both sets of investors is that they can achieve superior yields by assuming greater risk in previously non-core activity.

There has been a proliferation of Operating Company and Property Company structures as a result of the arbitrage opportunity. Investors are starting to look at the REIT market as another potential refinancing opportunity to utilise property assets acquired with an operating business. There is little doubt but that the weight of private capital that continues to be available both for business acquisitions and property investment means that the convergence of multiples will continue.

The heat being generated in the real estate market is leading most retail and leisure businesses to consider realising capital from their real estate assets. The capital can then either be returned to shareholders, used to retire debt or be invested in the core business. Though conceptually simple, releasing value from the property assets is complex from an operational, fiscal, and accounting standpoint. Businesses should consider the opportunity to take advantage of real estate investor demand very carefully and should at all times keep all aspects and consequences of the transaction in view. 
The most obvious issue for many organisations will be the tax liability that is likely to be triggered. The assets that are to be sold often have a low value for tax purposes, which means that capital gains on sale are likely to trigger significant tax liability. This needs to be considered very carefully at an early stage. Companies should think about the capital allowances position - is it important to retain allowances, or is the business better served by allowing the real estate investor to claim the benefit of them?

Sometimes less obvious will be the accounting treatment of a disposal of the assets. It will be important for most balance sheets that any leaseback of the assets is truly by way of operating lease rather than finance lease. The profit and loss recognition of the deal varies from jurisdiction to jurisdiction and again needs to be understood fully from the outset.

The tax and accounting treatment that the operating business is seeking to achieve are important factors in developing the optimal structure of the real estate disposal. It is important that the vendor is clear on all these points since it will influence the selection of target real estate investors and the negotiation of the terms of the lease and, indeed, the purchase price.

Operationally, the issues are at least as important. The lease structure should be driven by the core business need rather than the whims of the traditional landlord market. Factors to be considered include:

- Rent review provisions

- Lease term and flexibility

- Responsibility for, and approval of, capital works

- Restrictions on assignment

- Insurance

- Financial covenants

Softer, but nonetheless significant, considerations should also be taken into account. For example, for the sale itself does the Company want it to be discreet or front page news? Is the nature of the investor important? Is the Company seeking to build a continuing relationship with the investor or is it a one-off transaction? How important is the interaction with the new landlord over time? The answers to these questions will again influence the segment or segments of the investor market that are tapped for the transaction.

Historically, the property team in retail and leisure businesses has been kept somewhat at arm's length; they have simply been presented with requests to acquire or dispose of property to meet an operational or financial need - sometimes at short notice. The same team is blamed when, having acquired a building at the behest of the core business and there is a change of strategy or a reorganisation or abandonment of an initiative, that building suddenly becomes surplus to requirements. The lack of coordination between the property department and the rest of the business has meant that there has often been an imbalance between demand and supply. 
Just as damaging, the property team will from time to time come up with a 'cracking' property trade - and will pursue it - before the full operational, fiscal and accounting context has been understood and accommodated.

Overall, there has been a reasonable understanding of the supply side of the equation - 'what property is owned or leased?' - but a poor understanding of demand and what drives it - 'what will the core business need over the next few years?'

The property team can only understand demand dynamics by being integrated into the business and financial planning process. Similarly, the core business needs to be informed of the true cost of accommodation and the alternatives that are available. Finding the correct balance between supply and demand will be a function of both sides challenging each other. This is best done in an integrated forum.

Incidentally, it is equally important to ensure that property liabilities of all kinds are managed well - rent, rates, service charges, reinstatement and dilapidations costs, annual maintenance and life cycle replacement, for example.

The reality is that, in general, more dynamic and interactive planning is needed. Sound property asset management is founded upon a clear picture of both supply and demand and an all-encompassing view of costs and benefits.

There needs to be a 'de-mystification' of property. A property asset or liability is neither nothing more nor less complicated than a series of cash flows. These cash flows should be valued correctly. This involves recognising the true costs associated with using or investing in a property as well as the revenues it generates.

Similarly, proper stock should be taken of what property a business actually needs and whether it really needs to own it. There should be a great deal more comparative cost and benefit analysis of owning versus renting accommodation - not just for new property acquisition, but for the entire portfolio. Received wisdom must be systematically challenged: occupying a freehold property is not always cheaper than renting, for example. Asset values should be realistic and up to date.

The conclusions are that:

- Property asset management should be seen as integral to overall business and financial planning;

- Both demand for, and supply of property must be understood by those charged with executing the overall plan;

- Rigorous analysis and planning may lead to the debunking of received wisdom - and this should be welcomed; and

- Property disposals and acquisitions should be undertaken holistically - with a full understanding of the operational, financial, tax and accounting consequences.

Property should enable and not constrain the delivery of core business. Only high quality integrated asset and financial management will ensure that this is true. 